О. В. Тихоненко

\title{
ДЖЕРЕЛА ЗБАГАЧЕННЯ ЛЕКСИКИ ОФІЦЙНО-ДІЛОВОГО СТИЛЮ УКРАЇНСЬКОЇ МОВИ НА ЕТАПІ ЙОГО СТАНОВЛЕННЯ
}

\footnotetext{
Тихоненко О. В. Джерела збагачення лексики офіційно-ділового стилю української мови на етапі його становлення.

У статті описано джерела збагачення лексики в офіційно-діловому стилі української мови періоду 20-30-х рp. ХХ ст. Доведено ілюстративно, що до лексичного складу досліджуваного періоду входили не лише діалектна лексика, архаїзми, а й неологізми.

Ключові слова: офіційно-діловий стиль, літературні норми, тематичні групи лексики, канцеляризм, архаїзм, діалектні форми, неологізм.
} 


\section{СТРУКТУРА I СЕМАНТИКА МОВНИХ ОДИНИЦЬ}

Тихоненко Е. В. Источники обогащения лексики официально-делового стиля украинского языка на этапе его становлення.

В статье описаны источники обогащения лексики в официально-деловом стиле украинского языка периода 20-30-х гг. ХX ст. Доказано иллюстративно, что в лексический состав исследуемого периода входили не только диалектная лексика, архаизмы, но и неологизмы.

Ключевые слова: официально-деловой стиль, литературные нормы, тематические группы лексики, канцеляризм, архаизм, диалектные формы, неологизм.

Tykhonenko E. V. Enrichment of the vocabulary in the formation of the Ukrainian official anl business style.

In the article the sources of enrichment of the vocabulary are exposed in the Ukrainian official and business style in the $20-30^{\text {th }}$ years of the $20^{\text {th }}$ century. The author reasons, that in the researched period dialectal vocabulary, archaisms and neologisms are included to lexical composition.

Key words: official and business style, literary norms, thematic groups of vocabulary, kancelyarizm, archaism, dialectal forms, neologism.

Говорячи про історичні зміни в мові взагалі і в літературних нормах зокрема, необхідно мати на увазі, що інтра- та екстралінгвальні чинники цих змін постають разом, у діалектичній єдності. Як зазначає О.А. Стишов, «динамічні процеси в лексиці відбивають очевидні, відкриті, а також приховані механізми мовної еволюції» [4, с. 4]. На думку О. Г. Муромцевої, «новотвори певного історичного періоду передають у стислому вигляді досить широку інформацію про особливості економічного, політичного, культурного життя епохи, у них, як у зародку, виявляються ті мовні тенденції, які розвинуться в майбутньому» [3, с. 10].

Дослідження лексики $є$ важливими для функціональної стилістики [1-5], адже в офіційно-діловому мовленні, як і в мові взагалі, рухомий лексичний склад, що активно й безпосередньо реагує на всі соціально-економічні зрушення. Лексико-граматичні риси документів адміністративно-канцелярського різновиду найбільш динамічні. Вони змінювалися і під впливом соціально-історичних факторів, і залежно від жанрової належності та змісту документа. Соціальні процеси передусім відбиваються на змінах у мовному узусі. Слушною є думка Л. В. Струганець, що демократизація суспільства і пов'язана 3 нею демократизація літературної мови впливає на модифікацію статусу літературних норм [5, с. 312]. Отже, дослідження екстралінгвістичних чинників в офіційно-діловому стилі має вагоме 
значення для вивчення становлення й розвитку саме цього різновиду літературної мови та його норм.

Офіційно-діловий стиль своїм лексико-фразеологічним складом суттєво відрізняється від усіх інших стилів української мови. Усталена в ньому лексика зі стилістичного боку кваліфікується як книжний елемент. Цей різновид мовлення передбачає попереднє продумування, монологічний характер викладу, прагнення до логічної впорядкованості тексту, а також передачі думок лише традиційними мовними засобами - сувору нормативність і реалізацію саме книжної лексики. Лексичний склад офіційно-ділового стилю, як і вся сучасна організація мовного матеріалу, розглядаються з урахуванням певного періоду його становлення та розвитку, історії літературної мови, а також того безперервного руху, що $\epsilon$ наслідком упливу екстралінгвальних чинників, динаміки, яка відбувається у стильовій системі всієї літературної мови, відтворює життя мови на всіх їі рівнях i найвиразніше - на лексичному. Тому обрана тема $є$ актуальною в першу чергу з огляду на об'єкт дослідження.

Предметом є закономірності становлення лексики в офіційноділовому стилі української мови.

Мета статті - з'ясування джерел збагачення лексики офіційноділового стилю української мови у період його становлення (20-30-ті pp. XX ст.). Ілюстрації наведено відповідно до тогочасних правописних норм. Поставлена мета спричинила виконання таких завдань: 1) провести тематичну класифікацію; 2) визначити шляхи та способи поповнення лексичного складу; 3) проаналізувати склад лексики за походженням.

Процес збагачення лексики розглянуто на матеріалі термінів, зафіксованих у словниках, архівних документах періоду 20-30-х pp. XX ст., тобто при доборі матеріалу враховувалася як сфера фіксації лексики, так і сфера їхнього функціонування.

Джерельною базою слугували словники ділової мови періоду 20-30-х pp. XX ст.: Російсько-український діловодний словник Л. Падалки (Полтава,1918) - РУДС-1918; Українська мова. Російськоукраїнський словник та зразки паперів українською мовою Д. Лебедя (Чернігів, 1918)-РУС-1918; Російсько-український словник щонайпотрібніших у діловодстві слів. Практичний порадник М. Осипіва (Х., Полтава, 1926) - РУСДС-1926; Фразеологія ділової мови В. Підмогильного, Є. Плужника (К., 1927) - ФДМ-1927; Словник ділової С О. В. Тихоненко, 2012. 
мови. Термінологія та фразеологія (Проєкт) М. Дорошенка, М. Станіславського, В. Страшкевича (Х. -К., 1930) - СДМ-1930; Словарь русско-украинский В. Буряка (Одеса, б/p) - РУС-б/p.

Так, у 20-30-ті pp. XX ст. були помітні вагання науковців у питанні становлення мовних норм. Процес нормалізації має враховувати як усі хитання у використанні слів, що можуть бути необхідними навіть в одну й ту ж епоху, так і ті закономірності й правила мовної комунікації, що виникають разом 3 iї функціями й виявляються в загальноприйнятих способах використання лексики. Стильові норми офіційно-ділового стилю визначаються лише в конкретному контексті, де їхня вибірковість і сполучуваність може бути різною навіть залежно від жанрової належності. Крім того, нормативність $\epsilon$ історично змінним явищем.

На лексичному рівні в офіційно-діловому мовленні української мови норма виявилася в доборі й певній організації тематично зумовленої книжної, літературної, нейтральної загальномовної, іншомовної й інтернаціональної лексики, галузевої термінології й офіційно-ділової номенклатури.

Тривале вивчення архівних документів засвідчило, що процес становлення й розвитку стилю в пореволюційний період був надзвичайно бурхливим і мав послідовний характер демократизації всіх елементів мовлення, насамперед стильових норм. Період 20-х рр. покликав до активної юридичної, дипломатичної та урядово-адміністративної діяльності широкі народні маси, у результаті чого досліджуваний стиль, як i iнші стилі, надзвичайно збагатився народними лексичними елементами, що було закономірним і пов'язаним у першу чергу зі спрощенням окремих мовних форм і конструкцій, а також із прагненням до економії мовних засобів - як лексичних, так і граматичних.

Як бачимо, лексичну основу досліджуваного стилю складають загальновживані слова, звичайні та поширені назви предметів, явищ, дій і станів. Це загальновживана лексика (міжстильова), до якої належать слова, що становлять ряди лексики за значенням:

1) назви осіб за родинною ознакою: мати, батько, син, дочка, родич;

2) найменування осіб за дією: свідок, сторона, заявник, відповідач, вкладник, позовник, доглядач, наглядник, надписувач, повірений, обвинувач, кур'єр, дозорець, наглядач, наймач;

3) назви осіб за професією: візник (кучер), коваль, фарбар, купець, крамар, ливар, лікар, учитель, механик, робітник, працівник, 
архівар, журналіст, інспектор (городських телефонів), контролір (відділу руху), нотар, юрисконсульт;

4) назви частин тіла людини: голова, рука, око, вухо, серие;

5) назви заходів та відповідних дій: поторжки, торги (аукиііон), з зїз;

6) назви сфер людської діяльності, галузей знань: судочинство, судівниитво, будівництво, нотарство;

7) назви найуживаніших знарядь праці: машина (друкарська, парова), рахівничя, прилад (вимірювальний), стіл, телефон, підручник;

8) назви абстрактних понять: боротьба, життя, смерть, здоров'я, слава, доля, сила;

9) назви типових явищ суспільного життя, природи: сьогодні, витратити, читати, коштувати, їсти, стати, сніг, зима;

10) назви предметів повсякденного вжитку: ключ, книга, ножиці, скринька, тара, иухляда, ящик.

Найбільш поширеними 3-поміж представленої класифікації лексики за значенням виявилися назви осіб за дією та професією, а отже, така лексика становить ядро офіційно-ділового стилю.

На тлі загальновживаної лексики лексична система офіційноділового стилю 20-30-х рр. ХХ ст. має свою специфіку. До складу лексики цього стилю також належать стилістично обмежена лексика $\mathrm{i}$ канцеляризми. Стилістично обмежена лексика - це офіційно-ділова, представлена словами, рідше - сполученням слів, що $\epsilon$ повторюваними в писемному мовленні, яка найбільшою мірою сформувала офіційно-діловий стиль мови.

Спираючись на дослідження лексичної норми, в офіційноділовому стилі можна виділити такі основні тематичні групи лексики:

a) назви державних організацій, закладів і позадержавних об'єднань: міністерство, партія, клуб, икола, церква, офіиія, банк, бюро, будинок, гімназія, інститут, адміністрація, уряд, каса, комісія, комітет, товариство, біржа, відомство, філія, відділ, інспекція, рада, палата;

б) найменування осіб, що обіймають посади: президент, міністр, староста, директор, завідувач;

в) назви документів, цінних паперів: акт, заява, протокол, розписка, довідка, лист, папір актовий, вексель, декрет, патент, відомість, спис, витяг з протоколу, доповідна записка, позов, телеграма, атестат, звідомлення (звіт), договір, асигнація; 


\section{СТРУКТУРА І СЕМАНТИКА МОВНИХ ОДИНИЦЬ}

г) позначення обов'язкових елементів документа і можливих дій офіційних осіб: порядок денний, ухвалити, до наказу, розв'язати, дати вказівки, зобов'язатися.

Отже, у діловому мовленні ця лексика $\epsilon$ стилістично найдоречнішою й комунікативно вмотивованою.

Показовими в офіційно-діловому стилі досліджуваної доби виявилися канцеляризми, що за межами стилю втрачають свою стильову маркованість (довести до відома, вищевказаний, задекларувати, довірена особа, поіменований тощо). Вони виступають як обов'язкові компоненти стилю, а тому були зафіксовані в СДМ1930: нижчеподаний, вищуеподаний, вищеназваний, вищчевичислений, вищуенаписане, вищуезазначений, вищуеподаний, вищесказаний, вимепоказаний, вищезгаданий, нижченазваний (названий далі), нижчезазначений (зазначений далі), нижчепідписаний (цо підписався далі), нижченаведений (наведений далі), нижчеподаний (поданий далі, наведений далі) нижченаведений, згаданий далі, нижчезгаданий.

Специфіку лексичної системи офіційно-ділового стилю початку 20-х pp. ХХ ст. складає наявність у ній архаїзмів, які насамперед спостерігаються в документах РУС-1918: Уклінно прохаю дати мені посаду в підлеглій Вам фінансовій палаті. При сьому подаю такі відомосте про себе; Уклінно прохаю дозволити моєму синові: Семену Кривцю складати іспит; Але маючи на увазі, щуо особа, на сій посаді неодмінно повинна знати бухгалтерію; Надсилаючи при сьому, додатком до припису 18 квітня б. р. під № 21973, - копію реєстра нерухомого майна довіреного Вам складу, прохаю подбати про складання в найскоршім часі актів про надоби та майно, пограбовані та знищені в складі під час пожежи та грабунку.

У реєстрах словників ділової мови відбито такі архаїзми, як животіння, чини, рата, рамено (ФДМ-1927), хурман (СДМ-1930).

Простежуються діалектні форми (без ремаркування) й елементи живого народного мовлення (з ремаркуванням джерела - «словника живої мови») у СДМ-1930: причинки, уступ (уривок), перепаска (бандероль), оповістка (оголошення), передвістка (анонс), посесія (оренда), надбіжка, бариш, зиск (прибуток), вкладка (внесок, вклад), звідомлення, справоздання (звіт), відклад, відволока, зволікання, знесення (відміна), цуидулка (записка), правіж, справляння (стягування, покарання), офічія, заряд (відомство), офірувати (жертвувати), відвідини (візит), матура (атестат). 
Так, наприклад, у СДМ-1930 лише до слова ліщутамиія подавалася ремарка галищьке до російського еквівалента аукціон, інші ж слова не ремаркувалися як західноукраїнські або галицького походження (посесія, звідомлення, изидулка, матура, зиск, бариш, завідатель тощо). Очевидно, що упорядники словника підтримували ідею про те, що діалектизми такого типу могли ввійти до лексичної норми. Однак час показав, що згадані слова не знайшли підтримки щодо їх входження до складу української мови.

Важливим здобутком для мови були іï взаємостосунки iз західноукраїнським діалектом. Спостереження дають змогу констатувати, що західний вплив позначився на лексичній нормі 20-30-х pp. XX ст. Ця лексика перебувала на периферії мовного вжитку, що так і не соціалізувалася, не закріпилася в мові. Таке злиття живомовної народної стихії, книжної традиції та інтернаціональної лексики могло відбутися внаслідок тісної комунікації з носіями інших національних мов. Отже, літературна мова, зокрема ії офіційноділовий стиль, сприйняла із західноукраїнської практики лише те, що збагачувало й розширювало іiі лексичний склад.

Диференціація жанрів офіційно-ділового стилю зумовила активізацію лексики зі сфер дипломатії - меморандум, запросини, консул, консульство, кур'єр, посол, візита, одвідини, конвениія, компроміс, посольство, співробітництво, контрибуція, ратифікувати; юриспруденції - адвокат, адвокатура, оборонець (судовий), апелящія, апелювати, арбітраж, оскарження, оскаржити, авдієнџія, дорадник, арешт, ув'язнення; військової - армієць, ратник, армійський, армія, гарматник, артилерист, арсеналець, арсенальник, капітан, командир, командувач, командування, старшина; науки і освіти - асистент, аспірантура, дописувач, лекторія, стипендія, стипендіят.

Помічаємо також, що норми слововживання змінилися стосовно інтерпретації їх мовцями - носіями нової влади та ідеології; форми звертання пан, добродій, господар замінено в законодавчому мовленні, інколи в адміністративно-канцелярському на громадянин, громадянка, громада, а поряд 3 ними вживається товариш. Порівняємо: До Пана Управителя Полтавською Фінансовою Палатою; До Пана Директора Чернігівської Чоловічої Гімназї; До Пана Губерніяльного Старости Чернігівщиини (РУДС-1918) або Українська Громадо!; Товариші робітники і селяне!.

Постійний розвиток суспільства вимагає від мови сучасних (C) О. В. Тихоненко, 2012. 


\section{СТРУКТУРА I СЕМАНТИКА МОВНИХ ОДИНИЦЬ}

номінацій, оскільки вона повинна задовольняти потреби кожної людини. Зміни в суспільній, політичній, економічній та культурній сферах зумовлюють у мові зародження нових назв, зокрема творення неологізмів. Неологізми як своєрідний результат мовної практики соціалеми розуміємо як нові слова та словосполучення, що на певному синхронному зрізі розвитку мови були на периферії мововжитку i, як зазначалося вище, у подальшому не ввійшли до активного лексичного складу та словників. У 20-30-ті pp. XX ст. відмічається в літературному (у тому числі діловому) мовленні багато неологізмів у СДМ-1930: утвердний акт, акт на увласнення, авкція, безполадний, пересідний білет, шлюбованці, друженці, зокільний висад, стіннівка, банківство, виказувач, виказувачка, дрогіст, передмістянин, непорушенець, непорушнина, первісник, стоянина, навідник, окрад скарбу, коректа, правня, заставня, позбава, вирішнии, долегливо, необійденний, незамінний, нескасовний, неоказ, убезпечне, убезпеччина, крайниця, опікуваний, опікуванецьь, опік(ув)анка, упорядний, ображенець, відповідь невистачна, одниклива, скасовність, доділ, уємний, відстановленець, відстановленияя, вислуженець, переосвід, підтрим, наймане приміщення, приміщення у підмурах, підмур'я, підмури, оказовим способом, оказово, позбава прав, передступник, передступниия, оказовець, оказовичя, оказовнищький, розсил, дорозкішия, дорозкішні речі, рядчик, рядчий, співпозиванець, співпозиванка, зістава, співпрацівник, співпрацівниця, супрацівник, супраџฺівниця, вантажня, двійковий рахунок, облічник, обліковецьь.

3 появою нових органів державного управління змінилася номенклатура офіційно-ділового стилю: зникли назви урядових установ дума, департамент, сенат, сойм, палата, офіція, управа. Відродження державності спричинило появу нових органів влади, установ, як-от: рада, комітет, комісаріат, кооператив, контора, відділ. Також закріпилися назви заходів, що проводилися в установах, на підприємствах - збори (передвиборчі, загальні), наради, а також нові назви посад - комісар, голова.

Термінологія як невід'ємна характерна риса офіційно-ділового стилю випливає 3 особливостей соціальної функції ділової мови, яка в цілому обслуговує суспільні відносини, служить для зв'язку органів влади 3 населенням, взаємозв'язку установ та організацій, а також для міжнародних зв'язків у сфері політики, економіки, культури. В офіційноділовому спілкуванні активізується галузева термінологія, що використовується залежно від сфери вжитку. Це переважно термінологія

С О. В. Тихоненко, 2012. 
іншомовного походження, що входила в мову за рахунок відкритості іiі системи, рухомості й динамічності лексичного складу. Ї̈̈ склад поповнили насамперед суспільно-політичні терміни, запозичені 3 інших мов світу: агітатор (лат.), актив (лат.), банк (франц.), буржуазія (франц.), декрет (лат.), диктатура (лат.), командир (нім.), комісар (франц.), комітет (франц.), комунізм (франц.), конституція (лат.), політика (грецьк.), пролетаріат (нім.), район (франц.), секретар (франц.), соиіалізм (нім.); економічні: ажіо (італ.), варрант (англ.), вексель (нім.), жсро (італ.), індосамент (нім., італ.); інкасо (італ.), ломбард (італ.), тратта (італ.); технічні: індустрія (лат.), інженер (франц.), технік (грецьк.); юридичні: адвокат (нім.), прокурор (франц.), арешт (серендньолат.). Таким чином, найчисельнішою була лексика, яку фіксували словники ділової мови, запозичена з латинської, німецької, французької та італійської мов.

Розбудова торгівлі і промислової політики у 20-ті рр. сприяла входженню в українську мову відповідної старої, але семантично оновленої термінології, як-от: виручка, акцизний, депозит, ичиркуляр, кочторисні передбачення, приватна адвокатура, судове відомство, комериійний суд, третейський суд.

Проілюструємо входження до словників ділової мови термінології економічної сфери.

\begin{tabular}{|c|c|c|c|c|c|}
\hline Терміни & РУС-б/p & РУДС-1918 & РУСДС-1926 & ФДМ-1927 & СДМ-1930 \\
\hline аванс & аванз & аванс & аванс & аванс & аванс \\
\hline баланс & - & - & баланс & баланс & баланс \\
\hline банк & банк & банок & банк & - & банк \\
\hline виплата & сплата & $\begin{array}{c}\text { виплат, } \\
\text { оплат }\end{array}$ & виплат & виплата & $\begin{array}{c}\text { сплата; } \\
\text { видача } \\
\text { платні; } \\
\end{array}$ \\
& & & & & виплат \\
\hline квиток & - & $\begin{array}{c}\text { пашпорт, } \\
\text { картка }\end{array}$ & квиток & $\begin{array}{c}\text { білет, } \\
\text { банкнота }\end{array}$ & квиток \\
\hline податок & податок & податок & податок & податок & податок \\
\hline рахунок & $=$ кошт & рахунок & рахунок & рахунок & рахунок \\
\hline дебет & - & - & дебет & дебет & прибуток \\
\hline кредит & - & $=$ кредіт, & кредит & кредит & кредит, \\
& & віра & & & біра \\
\hline бюджет & бюджет & бюджет & бюджет & бюджет & бюджет \\
\hline
\end{tabular}

Стосовно лексичних змін в офіційно-діловому мовленні 20-30-х рр. XX ст., менших змін зазнала юридична, дипломатична, фінансова, 


\section{СТРУКТУРА І СЕМАНТИКА МОВНИХ ОДИНИЦЬ}

економічна, торговельна термінологія. Для специфічної лексики характерні переважно якісні семантичні зрушення: терміни набували нового соціального змісту, зберігаючи своє лексичне значення.

Як бачимо, економічний розвиток 20-30-х рр. (розвиток торгівлі i промисловості) позначився на мові документів, де спостерігаємо активізацію економічної термінології та номенклатури.

Ділова мова того часу була насичена не лише термінами, а й термінологічними словосполученнями: відкриті збори, порядок дня, питання державної ваги, платежеспроможний запит, революиійна совість, продовольчий комітет, продовольчий податок, хлібний інструктор, народна міліція, політика воєнного комунізму.

Отже, утворення i становлення нових органів державного управління, розвиток різноманітних галузей створили сприятливі обставини для розбудови терміносистеми, викликаної до життя потребами суспільства. Приклади засвідчують динамічні зміни в термінологіi, які викликали ऑï варіативність (як ознаку шліфування норм на етапі становлення). Це природний і логічний процес у мові, коли суспільство вдосконалює ділову мову, контролює створене і як результат закріплює його в системі комунікативних засобів залежно від сфери використання.

Показовим $є$ те, що процес неологізації лексичного складу, фіксований у досліджуваних словниках, наприклад, у СДМ-1930, зумовлений: 1) творенням лексики на власному грунті: тріумфальний лук (рос. Триумфальная арка), тріумфальні ворота; значка, бал (рос. Балл); броиура, метелик (рос. Брошюра); илюбованець, друженець (рос. Вступающий в брак); вокзал, дверецьь залізничний (рос. Вокзал); 2) засвоєнням іншомовних слів: сальдо, ломбард, варрант, бювар.

Вагання у становленні лексичних норм проявилися $\mathrm{y}$ варіантності на словотвірному та граматичному рівнях.

На рівні словотвірної будови утворено спільнокореневі похідні за допомогою варіантних афіксів:

а) суфіксів - артільщинна, аситнатний, аситнатовий; баришування, барииництвво; батальйонний, батальйонів; безправ'я, безправство; беззаконня, беззаконство; бюджетнии;; довгість, довгота; доморядецьь, доморядник; життьовий, життєвий; меліоративний, меліораційний; переписувач, переписник; переписувачка, переписниця; пересельський, переселенський; позичальник, позичник; продуктивність, продукиійність; спільницяя, спілчанка; ощзадливість, ощзадність; ненормований, ненормовий; 
б) префіксів - безплатний, неплатний; невпинно, безупинно; довірчий; перебування; безпечатний.

Таким чином виникали словотворчі дублети. Як бачимо, переважання суфіксальних варіантів частково можна пояснити спробою лінгвістів замінити поліфункціональні форманти, зокрема суфікси, на спеціалізовані, адже полісемантичність гальмує деривативну активність таких морфем i відповідно зумовлює тенденцію до втрати чіткості термінотвірного значення.

Граматичному рівню було властиве:

а) варіювання конструкції «прийменник + іменник» та однослівного позначення ознаки - безпаспортний, без паспорта; безслідно, без сліду; без прізвища, безпрізвищний; безпатентний, без патенту; бездоганний, без догани; без переміни, безперемінний; без помилки, непомилечний, непомильний; без печатки, безпечатний; безплатно, без плати;

б) утворення морфологічних варіантів, що характеризувалися варіантністю на рівні роду - контроль, контроля; бандероль, бандероля; кляс, кляса; плян, пляна .

Отже, поповнення лексичного складу офіційно-ділового стилю відбувалося за рахунок використання діалектної лексики, появи новотворів та запозичень. Залежно від сфери використання в мову документів поступово входила різногалузева термінологія. Разом із процесом унормування, кодифікації лексики простежуються вагання у творенні нової лексики в офіційно-діловому стилі, хоч значна частина слів усталилася в досліджуваний період й активно функціонувала. Названі явища в мові можна пояснити дією соціолінгвістичних факторів.

\section{Література}

1. Жовтобрюх М. А. Мова української періодичної преси (кінець XIX - поч. ХХ ст.) / М. А. Жовтобрюх. - К. : Наукова думка, 1970. - 304 с.

2. Коць Т. А. Літературна норма у функціонально-стильовій $\mathrm{i}$ структурній парадигмі : [монографія] / Т. А. Коць. - К. : Логос, 2010. - 303 с.

3. Муромцева О. Г. Розвиток лексики української літературної мови в другій половині XIX - на початку XX ст. / О. Г. Муромцева. - К. : Вища школа, 1985. - 152 с.

4. Стишов О.А. Динамічні процеси в лексико-семантичній системі та в словотворі української мови кінця XX ст. (на матеріалі мови засобів масової інформації) : автореф. дис. на здобуття наукового ступеня д-ра філол. наук : спец. 10.02.01 «Українська мова» / О. А. Стишов. - К., 2003. - 35 с.

5. Струганець Л. В. Динаміка лексичних норм української літературної мови ХХ століття / Л. В. Струганець. - Тернопіль : Астон, 2002. - 352 с.

Стаття надійшла до редакції 22.11.2012 p.

(C) О. В. Тихоненко, 2012. 